\author{
Małgorzata Jakubowska, Kamila Żyto \\ Uniwersytet Łódzki
}

\title{
Labirynt i kłącze - paradygmaty współczesnej narracji filmowej
}

Współczesne kino głównego nurtu podlega coraz większej dywersyfikacji. W dobie postępującej medializacji X Muza stoi w obliczu konieczności rozszerzenia i zróżnicowania swojej oferty. Celem jest spełnienie oczekiwań jak najszerszego grona potencjalnych odbiorców, zazwyczaj posiadajacych swobodny dostęp do wielu form przekazów audiowizualnych.

Zróżnicowanie i złożoność paradygmatów narracyjnych wykorzystywanych w mainstreamowym filmie współczesnym jest jednym z przykładów dążenia kina do dotrzymania kroku mediom oferującym bardziej skomplikowane struktury organizacji tekstu. Z jednej strony więc współczesne kino głównego nurtu zmienia swoje oblicze pod wpływem form narracyjnych, preferowanych przez nowe media (np. Internet czy gry komputerowe) i dla nich charakterystycznych, z drugiej asymiluje strategie narracyjne dotychczas wykorzystywane głównie na gruncie kina autorskiego czy awangardowego. Jest to oczywiście możliwe dzięki wyższemu poziomowi audiowizualnej świadomości i edukacji widzów, na co dzień stykajacych się z nielinearnymi formami narracyjnymi. Labirynt i kłącze to „paradygmaty” współczesnej narracji filmowej szczególnie chętnie dziś wykorzystywane w kinie, także gatunkowym kinie głównego nurtu. Warto więc podjąć próbę ich opisania i dookreślenia, a jednocześnie wskazania zasadniczych różnic i podobieństw pomiędzy tymi modelami.

\section{Labirynt jako struktura narracyjna}

Błędnik, a więc labirynt, w różnych tekstach kultury powraca jako wizualny motyw, symbol, metafora, ale także - jeśli nie przede wszystkim - jako matryca modelująca strukture narracyjna konkretnego dzieła. Zwłaszcza w filmie labiryntowe struktury narracyjne przeżywają swój renesans. Odnajdziemy je zarówno w kinie popularnym, jak i artystycznym. Błędnik jako specyficzny sposób organizacji przestrzeni narzuca swój konstrukcyjny rygor 
różnym poziomom dzieła filmowego, może determinować wygląd miejsc diegetycznych, kształtować w filmie czas, ale i dominować nad obydwoma tymi warstwami dzieła filmowego. Labirynt w kulturze to nie tylko obdarzony licznymi znaczeniami symbol związany z mitem, ale przede wszystkim struktura, a więc zespół formalnych parametrów, które stają się cechami filmowej czasoprzestrzeni, a co za tym idzie - konstrukcji całej narracji.

Ponadto narracja, która zdefiniujemy jako labiryntową znacząco wpływa na doświadczenie odbiorcy i bohatera. Wędrowiec, którego droge stanowi labirynt, znajduje się w specyficznej sytuacji, nieporównywalnej z sytuacja żadnego innego człowieka. Jest on więźniem przestrzeni, która penetruje, ale paradoksalnie więźniem obdarzonym swego rodzaju wolnościa wyboru. Bywa kojarzony z Benjaminowską figura flâneura, lecz błądzenie i wędrówka jest dla niego rodzajem wewnętrznego bądź zewnętrznego nakazu, a nie dobrowolnym życiowym wyborem. Ma w sobie trochę z Wiecznego Tułacza, choć nigdy nie rusza się z jednego miejsca. Sporo łączy go z wagabundą, ale trudno założyć, że - jak wagabunda - lubi ten rodzaj włóczęgi.

Paulo Santarcangeli - autor Ksiegi labiryntu - już na wstępie swoich rozważań zastrzega:

Im więcej łamiemy sobie głowę, tym lepiej zdajemy sobie sprawę, że przedmiot naszego zainteresowania, będąc labiryntem także i pod tym względem, nie da się rozwikłać przez definicję, która ujmowałaby go całkowicie i bez dwuznaczności. Zadowólmy się więc określeniem: «kręta trasa, na której czasem bez przewodnika łatwo jest zgubić drogę»1.

Jeśli więc da się stworzyć definicję labiryntu, to będzie ona definicją wyliczająca cechy wspólne większości labiryntów, aby na ich podstawie pokazać idee, jaka rządzi się ta struktura, a wraz z nia struktura filmowych narracji labiryntowych. Definicja taka powinna także uwzględniać doświadczenie związane z obcowaniem z błędnikiem.

Penelope Reed Doob i Werner Senn² wskazuja dwa typy form labiryntowych: unicrusal (labirynt, który ma tylko jedna, lecz długa, krętą i męcząca drogę, zwany też typem kreteńskim lub dedalijskim) i multicrusal (jego konstrukcja opiera się na konieczności podejmowania ciagłych wyborów, bowiem co rusz wędrowiec napotyka na rozwidlenia czy ślepe korytarze). Jednak to labirynty typu multicrusal zdominowały nasze myślenie, zdecydowanie wypierając ze świadomości labirynty unicrusal, stąd współczesna narracja filmowa przybiera kształt błędnika wielu dróg wyboru. Mówiąc o tego rodzaju skomplikowanej strukturze, trzeba podkreślić, że sposób jej organizacji jest zawsze celowy, a więc zaplanowany i przemyślany. Istnienie takiej formy nigdy nie pozostaje dziełem przypadku, nigdy nie jest pozbawione sensu, zawsze wynika z pewnego, z góry powziętego, założenia. Chwyty, techniki i rozwiązania (rozwidlenia, ślepe korytarze itp.), służace zbudowaniu konstrukcji labiryntowej,

\footnotetext{
${ }^{1}$ Paulo Santarcangeli, Ksiega labiryntu, przeł. I. Bukowski, Warszawa 1982, s. 41.

${ }^{2}$ Patrz: Werner Senn, The Labyrinth as a Structural Principle in Narrative Texts, [w:] The Structure of the Text, ed. Fries Udo, Tübingen 1987; Penelope Reed Doob, The Idea of the Labyrinth from Classical Antiquity throught the Middle Ages, New York-London 1993.
} 
stosowne sa nie jednorazowo, lecz systematycznie, z rozmysłem i dużą częstotliwościa. Zasadą rządząca błędnikiem będzie więc metodyczność myślenia, zwodzenia, wprowadzania w błąd. Metodyczna jest także ambiwalencja, główna zasada rządząca labiryntem. Jeden z jej podstawowych przejawów to rozdźwięk między chaosem na poziomie doświadczenia i porządkiem, jeśli chodzi o zamysł organizacyjny labiryntowej struktury. Elżbieta Rybicka pisze:

[...] labirynt - jako metafora aporii logicznej - już w swych początkowych dziejach niesie ze sobą ryzyko zabłądzenia i brak rozstrzygnięcia [...] jest on paradoksalnym splotem - pokrętną i zawikłaną, a jednocześnie misterną konstrukcja, bezwładnym, a celowym uporządkowaniem przestrzennym, emblematem logosu i jego aporią [podkr. - K.Ż.] ${ }^{3}$.

Anna Olejarczyk zauważa z kolei: „Labirynt to splot zagadek ontologicznych i etycznych. Węzeł logosu powstaje, jest dostrzegany, ale też - paradoksalnie - możliwy do rozsupłania tylko dzięki boskiemu i demonicznemu jednocześnie darowi rozumu"4. Labirynt to skrajny produkt rozumu, jego najbardziej skomplikowany wykwit, celowo sugerujacy chaos.

Zasadami rządzacymi labiryntowa struktura, ortodoksyjnymi i liberalnymi równocześnie, sa więc opisywane powyżej: metodyczność i celowość, rozpięcie między logosem i chaosem, porządkiem a brakiem ładu oraz dominanta sprzeczności i ambiwalencji. Oprócz tych ogólnych wyznaczników, regulujących budowę struktury, wpływających na doświadczenie tak zorganizowanej przestrzeni, istnieja jeszcze jej cechy podporzadkowane owym zasadom i je realizujące. Pierwszą kwestia wymagajacca poruszenia jest zamknięcie i wyizolowanie, które jednocześnie sprzężone jest z poczuciem względnej otwartości, bowiem za każdym zakrętem, pojawiają się nowe możliwości, potencjalne drogi jeszcze niepoznane, a prowadzace w zupełnie nowe, choćby tylko pozornie, rejony, dajace nadzieję na ucieczkę. Labiryntowa struktura to także, z jednej strony, brak, z drugiej zaś - nadmiar, a więc redundancja. Brak wynika z zamknięcia przestrzeni błędnika i powoduje poczucie unieruchomienia i bezwładu, nadmiar zaś prowadzi do niemożności wyczerpania wszystkich dróg, zapewnia pozór ciagłego podążania do przodu, jednocześnie stanowi o monotonii tego procesu. Równolegle więc w obrębie labiryntu istnieja progresywność i dygresywność procesu poznawczego. Nadmiar przestrzeni, o którym była mowa, jest rezultatem kolejnej cechy labiryntowej, a mianowicie multiplikacji. Jak pisze Rybicka:

Do specyficznie labiryntowych efektów zaliczyć także należy różnego rodzaju powtórzenia. Analogicznie do błądzenia w pokrętnych korytarzach i nieuchronnych powrotów do tych samych miejsc repetycje pełnią funkcję, po pierwsze retardacyjna, odraczająca progresywny ruch (fabuły, myśli) i rozwiązanie, po drugie, podkreślają znaczenie samego procesu dochodzenia i aktywności poznawczej wobec nieosiagalnego celu ${ }^{5}$.

${ }^{3}$ Elżbieta Rybicka, Formy labiryntu w prozie polskiej XX wieku, Kraków 2000, s. 14-15.

${ }^{4}$ Anna Olejarczyk, „Labirynt absurdu, absurd labiryntu”, „Acta Universitatis Wratislaviensis" 1998, nr XXXIII, s. 52.

${ }^{5}$ E. Rybicka, op. cit., s. 46. 
Owo namnażanie przestrzeni związane jest z kolei z inna „chorobą”, która trawi labiryntowe struktury, a mianowicie fragmentarycznościa. W labiryncie nie ma bowiem idealnych replik, sa tylko ich złudzenia. Choć wydaje nam się, że byliśmy już w konkretnym korytarzu, pokonaliśmy dane rozwidlenie, podjęliśmy jakaś decyzję i przyjęliśmy jej skutki, to po chwili okazuje się, że znajdujemy się w miejscu i sytuacji pozornie podobnej, przekształcajacej się w inną, także już nam znana. Labirynt jest bowiem zestawieniem, kompilacją fragmentów różnych miejsc, ich powieleniem i niepełną rekonstrukcją, której zasadą jest podobieństwo i różnica jednocześnie.

\section{Kłącze jako proces narracji}

Umberto Eco zaproponował w Dopiskach na marginesie „Imienia róży” strukturę kłącza jako ponowoczesną formę labiryntu ${ }^{6}$. Badacz odwołuje się do filozofii postmodernistycznej i z niej wywodzi przemiany następujące w narracji i swoistą ewolucję struktury labiryntu. Kontekstem są tutaj rozważania Gillesa Deleuze'a i Felixa Guattariego, traktujące książkę-kłącze jako przeciwieństwo wobec modelu drzewa i korzeni (palowego i wiązkowego), które obrazują tradycyjny, metafizyczny system myślenia opartego na władzy rozumu. Kłącze jest w ich ujęciu „modelem” myśli nomadycznej; nie tyle wyraża strukture, co proces. Myśl nomadyczna - nowy wizerunek filozofii, która postulują filozofowie, przywołując kłącze - charakteryzuje „nieobecność arche, organizującej zasady, jak i nieobecność apriorycznego ładu, w oparciu o arche konstytuowanego. Ta nieobecność modelu, centralnego miejsca, czyni z układu system zdecentrowany czy też centryczny, tworzony przez rozbieżne (dywergentne) serie elementów" . W ujęciu botanicznym kłącze to dziczka, skomplikowany system pędów, podziemnych lub naziemnych korzeni i odrostów. Jednak metafora dotyczy zarówno procesu myśli, jak i wyobrażenia świata: rośliny tworzą kłącze z wiatrem, słońcem, deszczem, z wirusami, bakteriami, zwierzętami i ludźmi. Rhizome charakteryzują zasady łączności (dowolny punkt kłącza można połączyć z innym), heterogeniczności (kłącze jest niejednorodne, tworzy sieć powiązań między różnorodnymi elementami), wielości (łatwość multiplikacji) oraz nie-znaczącego zerwania (system odnawialny, nieustannie zmieniajacy się) $)^{8}$. Zasady, które nie określają reguł porządku. Wręcz przeciwnie - generują nieporządek: nieograniczony rozrost, spontaniczność i chaotyczność kłącza.

${ }^{6}$ Umberto Eco, Dopiski na marginesie „Imienia róży”, [w:] idem, Imię róży, przeł. A Szymanowski, Warszawa 1996, s. 613.

${ }^{7}$ Bogdan Banasiak, Filozofia Gillesa Deleuze'a - fragmenty, [w:] Foucault, Deleuze, Derrida, red. Bogdan Banasiak, Kajetana M. Jaksender, Andrzej Kucner, Toruń 2011, s. 176.

${ }^{8}$ Por. Gilles Deleuze, Felix Guattari, Ktacze, przeł. Bogdan Banasiak, „Colloquia Communia" 1988, nr 1-3, s. 221-237. Analizę kategorii kłącza na tle filozofii Deleuze'a znajdzie czytelnik także w pracy: Małgorzata Jakubowska, Teoria kina Gillesa Deleu$z e ’ a$, Kraków 2003, s. 32-34. 
Narracja-kłącze i narracja-labirynt funkcjonują we współczesnej narratologii jako kategorie opozycyjne bądź mające wiele wspólnych cech. Co zatem łączy te „modele”, a co je odróżnia?

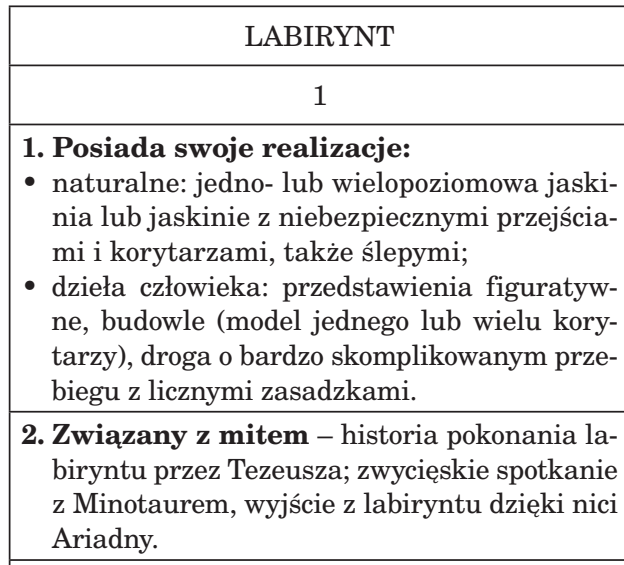

3. Funkcjonuje jako metafora lub symbol związany z mitem.

4. W znaczeniu przenośnym:

- człowiek-labirynt;

- proces mentalny jako labirynt;

- tekst (literacki lub filmowy) jako struktura labiryntowa występujaca w dwóch formach: przedstawienie labiryntu oraz labirynt przedstawiajacy;

- świat-labirynt (w domyśle: do pokonania przez człowieka).

\section{Model strukturalny odwołujący się do procesu/doświadczenia:}

- błądzenia czy uwięzienia w labiryncie (ale z nadzieja odnalezienia drogi - pokonania labiryntu i uwolnienia);

- panowania nad labiryntem (z perspektywy konstruktora);

- labirynt jako próba: powinność wobec siebie $\mathrm{i}$ innych, aby dotrzeć do celu.

\section{Cechy labiryntu}

Różnice:

- struktura zamknięta, skończona, oparta na binarnej opozycji „wewnątrz” - „na zewnątrz”;

- statyczny, niezmienny, nie posiada zdolności do przeobrażania się;

- labirynt jest ograniczony, ma skończoną liczbę rozwidleń, przejść, pułapek i korytarzy; u jego podstaw leży jedność - chęć odnalezienia centrum i właściwej drogi na zewnątrz;

\section{Posiada swoje realizacje:}

- naturalne: roślinne (np. perz lub inne rośliny rozmnażające się wegetatywnie) oraz zwierzęce (np. populacja szczurów);

- dzieła człowieka: Internet, hipertekst, gry komputerowe.

\section{Niezwiązane $z$ mitem}

3. Funkcjonuje jako metafora związana z myśla postmodernistyczną; z filozofią Gillesa Deleuze'a i Felixa Guattariego.

4. W znaczeniu przenośnym:

- człowiek-kłącze (Ja = nie ja i/lub Ja = Inni);

- proces mentalny jako kłącze, inaczej - myśl nomadyczna;

- książka-kłącze (analogicznie film lub inne teksty kultury);

- świat-kłącze (w domyśle: pluralizm, współegzystencja i walka sił, w której bierze udział człowiek).

5. Proces/doświadczenie w myśli nomadycznej odwołujacy się do modelu antystrukturalnego, wskazujący na błądzenie lub uwięzienie permanentne (nie sposób kłącza pokonać), bez możliwości panowania nad kłączem, bez konieczności dotarcia do wyznaczonego przez kogoś celu. Zamiast powinności - wielość dróg i możliwości.

\section{Cechy kłącza}

Różnice:

- proces otwarty, nieskończony, nie uznaje żadnych linii demarkacyjnych, odrzuca podział na to, co „wewnątrz” i „na zewnątrz” - można być tylko wewnątrz kłącza;

- ma charakter labilny, zmienny, podlega ciagłym metamorfozom i przekształceniom, bowiem każdy jego punkt może się połączyć z dowolnym innym punktem, a zasady tej koniunkcji są arbitralne; łatwo je odwrócić i zdemontować; 


\begin{tabular}{|c|c|}
\hline 1 & 2 \\
\hline $\begin{array}{l}\text { - zazwyczaj posiada centrum i jest struktura } \\
\text { hierarchiczna, może mieć też wiele centrów } \\
\text { lub nie mieć żadnego, jednak i w takim wy- } \\
\text { padku wędrowiec będzie na ogół zakładał ist- } \\
\text { nienie centrum i dażył do jego odnalezienia; } \\
\text { hierarchiczne jest też założenie istnienia wła- } \\
\text { ściwej drogi wiodącej do wyjścia. } \\
\text { Podobieństwa: } \\
\text { - osoba, która po raz pierwszy przemierza la- } \\
\text { birynt może mieć wrażenie, że jest on struk- } \\
\text { tura dynamiczna; } \\
\text { - działanie czasu i roślin może zmienić konstruk- } \\
\text { cję labiryntu; jakieś przejścia lub korytarze } \\
\text { moga zawalić się, w ścianach moga pojawić się } \\
\text { otwory, których wcześniej nie było i nowe drogi; } \\
\text { - model multicrusal hołduje zasadzie wielości } \\
\text { (droga wielu wyborów) i jako proces wędrów- } \\
\text { ki może być nieskończony (błądzenie i uwię- } \\
\text { zienie w labiryncie); } \\
\text { - jeśli nie posiada centrum, także jego hierar- } \\
\text { chia staje się watpliwa i ambiwalentna; } \\
\text { - wykazuje również zdolność generatywna: } \\
\text { zamiany innych struktur na struktury labi- } \\
\text { ryntowe. }\end{array}$ & $\begin{array}{l}\text { - kłącze, i jako proces, i jako model, jest nie- } \\
\text { ograniczone i nieskończone; jest ekspansyw- } \\
\text { ne, bezustannie rozrasta sie; } \\
\text { - jest oparte na zasadzie wielości: pluralizmu } \\
\text { i różnorodności; } \\
\text { - acentryczne, pozbawione hierarchii; nie ma } \\
\text { wyjścia, nie ma zatem właściwej drogi przez } \\
\text { nie wiodácej. } \\
\text { Podobienstwa: } \\
\text { - bycie „,wewnatrz” kłącza przypomina błądze- } \\
\text { nie w labiryncie wielu dróg; } \\
\\
\text { - posiada zdolność pochłaniania innych struk- } \\
\text { tur: może zawierać w sobie modele poprzednie: } \\
\text { korzeń palowy lub wiazke, ale także modele la- } \\
\text { biryntu o jednej lub wielu ścieżkach/jako wcze- } \\
\text { śniejsze formy skomplikowanej struktury. }\end{array}$ \\
\hline $\begin{array}{l}\text { Różnice fundamentalne: } \\
\text { - labirynt narracyjny jest lub może być obra- } \\
\text { zem świata lub jego cześci, } \\
\text { - funkcjonuje w ramach mimetyzmu, choć pod- } \\
\text { ważanie zasad racjonalności w „labiryntach } \\
\text { przedstawiających”, może prowadzić także do } \\
\text { osłabienia mimesis jako zawsze obowiązują- } \\
\text { cej reguły. }\end{array}$ & $\begin{array}{l}\text { Różnice fundamentalne: } \\
\text { - książka-kłącze nie obrazuje świata, jest jego } \\
\text { częścia, kino stanowi kłącze ze światem-obra- } \\
\text { zem; } \\
\text { - zachowana zostaje zasada łączności i bra- } \\
\text { ku granic, dzięki czemu wykluczony zostaje } \\
\text { wszelki mimetyzm. }\end{array}$ \\
\hline
\end{tabular}

Można zatem wskazywać na różnice lub podobieństwa między „modelami” lub „procesami”. Temu służyło rozbudowanie teoretycznej tabeli zaproponowanej przez Kamilę Żyto ${ }^{9}$. Trzeba jednak mieć na uwadze względność rozstrzygnięć i często po prostu operacyjną rolę tych pojęć wobec analizy dzieła artystycznego, które wymyka się tradycyjnym strukturom narracji. Jeśli badamy narrację labiryntową z perspektywy doświadczenia (bohatera bądź odbiorcy), wskazujemy na proces, co ukazuje wiele podobieństw z kłączem. Gdy w kłączu wskazujemy na elementy jego „struktury” umożliwiajacej określony proces, zbliżamy się do modelu labiryntu. W konsekwencji należy przyjąć, że nie sa to „modele” narracji, które podlegaja precyzyjnej definicji, w czym tkwi ich niewątpliwa siła, ale także słabośćc ${ }^{10}$.

${ }^{9}$ Por. Kamila Żyto, Strategie labiryntowe w filmie fikcji, Łódź 2010, s. 36-37.

${ }^{10}$ Pisałam o tych zagadnieniach, gdy analizowałam filmy Davida Lyncha. Por. Małgorzata Jakubowska, Żeglowanie po filmie, Kraków 2006, s. 127-222. 
Wymienione cechy labiryntu - takie jak ambiwalencja, zamknięcie z niemożliwością wyjścia poza (a właściwie uznanie, że kłącze jest jedynym zewnętrzem, stąd podział na wnętrze i zewnętrze zostaje odrzucony), otwartość wynikająca z nieskończoności, redundancja i multiplikacje czy fragmentaryczność - są także charakterystyczne dla nieograniczonego rozrostu kłacza i odwołując się do nich możemy opisywać narracje-kłącza. O ile podobieństwo i różnica wyznaczaja doświadczenie labiryntowe, o tyle różnica i powtórzenie to wyznaczniki kłącza, sięgające filozoficznych ustaleń Deleuze'a. W tym pozornie nieistotnym pojęciowym rozróżnieniu ukryte jest zaplecze ontologiczne i epistemologiczne tej filozofii. Podobieństwo wpisuje się bowiem w strategię władzy intelektu i przywołuje kategorię mimesis (coś jest podobne do czegoś, coś jest pierwsze, ważniejsze, tworzy genealogię itd.), narzucając interpretację. Natomiast powtórzenie unika interpretacji logocentrycznej, wskazuje na rejony intensywności, dające się łączyć z różnymi hipotezami. Podobieństwo domaga się ustalenia pierwowzoru, powtórzenie wprawia w ruch interpretacje, ale pragnie zachować ich wielość.

Kłącze nie jest celowe i metodyczne, co uzmysławia po raz kolejny wpisane w labirynt zasady logiki jako ważną cechę różnicująca. Bohater, który żyje w kłączu wydarzeń, jest zdany na chaos, przypadek, różnice sił, z którymi walczy lub które wykorzystuje. Kłącze nie daje się rozsupłać za pomocą logicznego myślenia, a wręcz przeciwnie - logika raczej tu szkodzi, a nie pomaga. Egzystencjalnie, światopoglądowo to diametralnie inna sytuacja niż znalezienie się w labiryncie, z nadzieją, że intelekt pomoże nam odnaleźć nić Ariadny i wyjście z pułapki.

Trzeba jednak zwrócić uwage, że na poziomie metatekstowym kłącze może być celowa strategia kompozycyjna, metodycznie stosowana w filmie przez artystę, choć kompozycja świata przedstawionego ukazuje brak celowości jako jego najważniejszą cechę.

\section{Strategie labiryntowe $w$ filmie fabularnym}

W filmie wyróżnić należy dwa rodzaje strategii labiryntowych. Po pierwsze, w kinie przygodowym, horrorach, fantasy czy science fiction najczęściej wykorzystuje się strategię labiryntów przedstawionych. Możemy o nich mówić wtedy, gdy labirynt staje się matrycą modelująca przestrzeń filmowa, a czas i związki przyczynowo-skutkowe pozostaja nienaruszone, a więc w rezultacie zachowuja swą odrębną strukture i nie ulegają dyktatowi formalnemu narzucanemu przez strukturę błędnika. Labiryntem staje się wtedy na przykład statek kosmiczny czy odległa planeta (por. wszystkie części serii Obcy: Obcy - ósmy pasażer Nostromo Ridleya Scotta, 1979; Obcy - decydujace starcie Jamesa Camerona, 1986; Obcy 3 Davida Finchera, 1992; Obcy: przebudzenie Jean-Pierre Jeuneta, 1997). Układ labiryntu może także przyjmować inne miejsce akcji (przykładowo: hotel Overlook w Lśnieniu Stanleya Kubicka, 
1980; dom w Azylu Davida Finchera, 2002). W takim wypadku obecność struktur labiryntowych w filmie, choć znacząca, nie eliminuje - pomimo tego, że sama charakteryzuje się dużą nieciagłościa, dystrofia, fragmentarycznościa i alinearnościa - obecności ciagłej, jednolitej i opartej na zasadzie wynikania skutków z przyczyn fabuły, której logika pozostaje do samego końca niezachwiana i spójna. Labirynty przedstawione to takie, które sa immanentnie zawarte w tekście, a więc bardziej się o nich opowiada niż opowiada się nimi. Choć przestrzeń filmowa w tym wypadku nabiera cech labiryntowych, to jednocześnie może być przestrzenią znarratywizowana, podporządkowana opowiadaniu pewnej historii i konstruowana tak, aby widz uzyskał maksimum informacji potrzebnych mu do zrekonstruowania fabularnego przebiegu wydarzeń. Tak więc doświadczenie labiryntu jako przestrzeni obcości staje się udziałem bohaterów. Widz, poprzez proces identyfikacji, może z nimi dzielić to doświadczenie na poziomie emocji, ale nie staje się ono jego udziałem jako składowa procesu poznawczego. O żywotności struktury labiryntowej, która przekształca toposy przestrzenne, a więc obecności strategii labiryntów przedstawionych we współczesnym kinie, świadczą takie filmowe tytuły ostatnich sezonów jak Piła II, 2005, w reżyserii Darrena L. Bousmana; Doom, 2005, Andrzeja Bartkowiaka; Zejście, 2005, Neila Marshalla; Resident Evil, 2002, Paula W. S. Andersona. W przywołanych obrazach mamy do czynienia z domem-labiryntem, jaskinią o błędnikowej konstrukcji, siedzibą korporacji, która więzi swoich pracowników. Przykłady można by mnożyć.

Jeśli jednak transformacji na kształt struktury błędnika ulega czasoprzestrzenna struktura świata diegetycznego, a co za tym idzie - staje się ona niespójna, nieciagła i wielowarstwowa, to mamy do czynienia ze strategia labiryntów przestawiających. Niemożliwe staje się opowiadanie o takim świecie w trybie klasycznej, arystotelesowskiej narracji podporzadkowanej hegemonii związków przyczynowo-skutkowych i hołdującej zasadzie linearności. O wydarzeniach rozgrywających się po wielokroć, lecz w różnych przebiegach temporalnych, których na dodatek nie da się uspójnić i wobec siebie zrelatywizować za pomoca racjonalnego trybu wyjaśniania, a więc poprzez analogię do rzeczywistości, nie sposób także opowiadać w sposób jasny i klarowny. Skoro labirynt to struktura doświadczenia, której obca jest wszelka jedność, spójność, jasność i klarowność, to narracja opisująca poruszanie się w środowisku labiryntowym wykazuje takie same właściwości. W filmach stosujących strategię labiryntów przedstawiających wszystkie elementy składające się na narrację (przestrzeń, czas, postaci, wydarzenia) zostaja poddane dyktatowi tych samych drakońskich zasad narzucanych przez strukturę błędnika. Powtarzanie się, nadmiar, ambiwalencja między logosem i chaosem przestrzeni, wydarzeń i postaci, sa jednak przede wszystkim konsekwencją przekształceń, które w pierwszym rzędzie zachodzą na poziomie czasu. Mamy w rezultacie do czynienia z narracją labiryntowa, która, jak pisze Michał Głowiński: „o labiryncie nie tylko opowiada, ale także opowiada labiryntem"11. Film snuje opowieści za pomoca obrazów, a więc

${ }^{11}$ Michał Głowiński, Labirynt. Przestrzeń obcości, [w:] idem, Mity przebrane, Kraków 1990. 
wizualizuje historię (plot), dlatego też zaproponowany przeze mnie termin „labirynty przedstawiajace" najlepiej oddaje istotę sprawy. W filmach, w których następuje dystrofia czasu, a co za tym idzie przestrzeni, fabuła jako rezultat labiryntowej narracji jest elementem, którego nie sposób zrekonstruować. Jest ona bowiem niespójna, nielinearna, nieciagła, pojawia się w wielu alternatywnych wersjach tak samo prawdopodobnych i wzajemnie nieredukowalnych. Mamy więc do czynienia raczej z wariantami pewnych wydarzeń, a nie z ich właściwym przebiegiem. Co więcej, jedność nie jest odzyskiwana nawet z końcem filmu. Zakończenie niczego nie wyjaśnia, nie przynosi żadnych rozstrzygnięć, a z pewnością nie sa to rozstrzygnięcia dające odpowiedź na pytanie o to, co się stało. Logika przyczyn i skutków zostaje całkowicie anulowana i unieważniona, zasada staje się jej brak. Oczekiwania widza sa wciąż burzone i kwestionowane. Jego przypuszczenia nie znajduja potwierdzenia i jest to stan permanentny, a nie przejściowy. Brak tu „szablonów narracyjnych” (template narrative schema), jeśli ograniczyć je do „kanonicznego formatu opowiadania” (canonic story format). Horyzont poinformowania oraz komunikatywność - Bordwellowskie kryteria różnicowania i analizy tekstów narracyjnych - uzyskuja bardzo niski poziom realizacji lub są nieobecne. Wysoki za to wydaje się stopień samoświadomości, czyli ujawnienia się instancji autorskiej. Taka labiryntowa narracja, w moim przekonaniu, jest podporzadkowana innym celom i funkcjom niż „kanoniczny format opowiadania”. Struktura labiryntowa determinujaca temporalne przebiegi, generuje alternatywny model narracyjny, zrywa zaś z modelem klasycznym, czyli takim, w obrębie którego w finale - bez względu na przesunięcia czasowe, retrospekcje, zmiany punktu widzenia czy instancji narracyjnej - możliwe jest odtworzenie opowiadanej historii, gdyż dostarczone informacje wzajemnie się uzupełniają i tworza koherentna całość, dajaca się usensownić, a wszelkie zaburzenia maja tu charakter przejściowy. Labirynty przedstawiajace jako element składowy czy wyjściowy moga wykorzystywać struktury przestrzenne mniej skomplikowane: koło lub konstrukcje szkatułkowa, na co dobitnie wskazuja realizacje Christophera Nolana: Memento (2000), Incepcja (2010). Finalnie jednak to zagubienie bohatera oraz dezorientacja widza przesadzaja o labiryntowym charakterze narracji. W wypadku labiryntów przedstawionych charakterystyczne dla błędnika doświadczenie staje się przede wszystkim udziałem odbiorcy, który nie jest w stanie zrekonstruować zdarzeń, ani powiedzieć, jak kończy się historia i jaki miała przebieg, a więc tkwi w labiryncie domysłów i wątpliwości, wyborów i możliwości, jakie podsuwa paradygmat narracyjny labiryntów przedstawiajacych.

Istnieją także i takie dzieła, w których obie te strategie współistnieją. Doskonałym przykładem sa przywoływane już Lśnienie Kubricka czy Incepcja Nolana. W obu wypadkach labiryntowości przestrzeni diegetycznych towarzyszy labiryntowość na poziomie narracji. Innym ciekawym przykładem może być eXistenZ (1999) Davida Cronenberga. Film ten, opowiadajacy o zagubieniu rozciagającym się pomiędzy rzeczywistością a światem wirtualnym, jest przykładem tego, jak istotny wpływ na popularność labiryntu jako paradygmatu narracyjnego maja nowe media. 


\section{Narracja-kłacze w filmie fabularnym}

Jak już wskazywałyśmy, w badaniach teoretycznych narracje-labirynty i narracje-kłącza mają wiele wspólnych cechy kompozycyjnych, które przeciwstawiaja je tradycyjnym regułom opowiadania filmowego. Świat diegetyczny ukazujący proces kłącza wpływa na przemiany czasoprzestrzeni, wydarzenia i samych bohaterów, generując dezorientację i niemożność rekonstrukcji opowiadanej historii - analogicznie wobec kompozycji, które Kamila Żyto określa jako labirynty przedstawiajace. Można zatem wobec filmów takich jak Memento, Incepcja czy eXisten $Z$ posłużyć się w analizie kategorią kłącza, jeśli chcemy podkreślić „nieobecność apriorycznego ładu” oraz sprzeczne hipotezy generowane przez te narracje, szczególnie co do ontologicznego i epistemologicznego statusu ukazywanego świata. Analizowane przeze mnie filmy Wojciecha Jerzego Hasa: Sanatorium Pod Klepsydra (1973) i Rękopis znaleziony w Saragossie (1964) także wpisują się - ze względu na kształtowanie czasu, przestrzeni oraz wyłaniającej się z nich narracji - w strategię kłącza ${ }^{12}$. Innym filmem, który ujawnia myślenie nomadyczne jest realizacja Denisa Villeneuve'a Enemy (2013). Zastosowanie w nim metafory pajaka i pajęczyny zdaje się być zaproszeniem do stosowania „modelu” kłącza jako sieci. Wprowadzone w tekst „nierozstrzygalniki” prowadza do sprzecznych interpretacji, z których żadna nie jest w pełni satysfakcjonująca intelektualnie, ale współistnieja jako możliwe kierunki odczytań. Przed podobnym zabiegiem zastosowania schizofrenicznej wizji, gdzie ja = nie-ja stawał widz oglądajac Fight Club (1999) Davida Finchera. Jeśli zastosujemy strategię labiryntu, z jego tendencja wiary w intelekt, pojawia się sugestia przezwyciężenia choroby przez rozum. Narracja-kłącze, kwestionując możliwości intelektu sugeruje inne odczytanie finałowej destrukcji: nie tyle zwycięstwo logosu, co chaosu.

Narracja-kłącze może także zostać użyta do łączenia różnych konwencji gatunkowych. Opowieść o dwóch siostrach (2003), która wyreżyserował Kim Jee-woon zawiera ściśle splecione dwie linie interpretacyjne: jedna odnosi się do choroby psychicznej dziewczynki i jej subiektywnej, psychotycznej wizji, druga zaś, wprowadzając konwencje horroru, każe odczytywać działanie sił nadprzyrodzonych jako immanentne cechy obiektywnego świata i nie wskazuje zaburzeń psychicznych dziecka jako ich przyczyny, co najwyżej skutek.

\section{Podsumowanie}

Czytelnik nie otrzymuje od nas jednoznacznego rozstrzygnięcia, która z tych kategorii lepiej, w sposób bardziej zasadny, można wykorzystać w analizie filmów o skomplikowanej, nieklasycznej narracji. Tekst ten prezentuje cechy obu „modeli”, ale nie przesądza o tym, który z nich jest bardziej funkcjonalny.

${ }^{12}$ Por. Małgorzata Jakubowska, Krysztaty czasu: Kino Wojciecha Jerzego Hasa, Łódź 2013. 
Obie strategie traktujemy jako narzędzia, które można zastosować w analizie, wskazując jednocześnie, że modele labiryntu i kłacza nie sa neutralne i obiektywne w tradycyjnym sensie przypisywanym teoriom. Różnice i podobieństwa, dotyczace cech kompozycyjnych często okazuja się względne, bowiem to badacz buduje dla nich kontekst w swojej analizie i interpretacji.

Fundamentalny wydaje się aspekt światopoglądowy, w który uwikłane sa narracje-labirynty i narracje-kłącza. Widz-metafizyk będzie chciał odnaleźć rozwiązanie zagadki, obronić rozum i racjonalność świata, nawet jeśli narracja będzie umożliwiała także inne odczytanie. Widz-ironista nie szuka rozstrzygnięć, ale właśnie w postawieniu problemu, krytycznej postawie i wielości hipotez widzi wartość tego typu narracji. Ostatecznie labirynt wyraża świat uporządkowany i celowy (lub tęsknotę za takim światem). Jest zbudowany na kulcie rozumu, nawet jeśli ten jest krytykowany czy kwestionowany, na przykład za sprawą choroby psychicznej bohatera. Natomiast kłacze - to świat nieuporządkowany, bez reguł, który sam dla siebie staje się celem. Jest kultem życia jako chaosu, w którym destrukcja splata się rozwojem.

Po stronie labiryntu, jako jego fundament, znajduja się SIŁY ROZUMU, skierowane na opanowanie emocji; świadome wygrywa z nieświadomym, a rozum poddany próbie wychodzi z niej zwycięsko.

Po stronie kłącza pierwszeństwo mają SIŁY WITALNE - żywioł emocji, afektów, popędów; świadome i nieświadome zrastają się w kłącze, a życie jest ujmowane jako Eros i Tanatos

Narzędzie metodologiczne, służące badaniu temporalnej organizacji narracji, nie ma, wbrew pozorom, „przezroczystego" charakteru i analizujacc struktury narracyjne, powinniśmy mieć tego świadomość. Narracja - czas światopogląd to triada, którą należy rozpatrywać łacznie, uwzględniając ich wzajemne wpływy i zależności.

\section{Bibliografia}

Banasiak B., Filozofia Gillesa Deleuze'a - fragmenty, [w:] Foucault, Deleuze, Derrida, red. B. Banasiak, K. M. Jaksender, A. Kucner, Toruń 2011.

Deleuze G., Guattari F., Kłacze, przeł. B. Banasiak, „Colloquia Communia” 1988, nr 1-3.

Eco U., Dopiski na marginesie „Imienia róży”, [w:] idem, Imię róży, przeł. A. Szymanowski, Warszawa 1996.

Głowiński M., Labirynt. Przestrzeń obcości, [w:] idem, Mity przebrane, Kraków 1990.

Jakubowska M., Teoria kina Gillesa Deleuze’a, Kraków 2003.

Jakubowska M., Żeglowanie po filmie, Kraków 2006.

Olejarczyk A., „Labirynt absurdu, absurd labiryntu”, „Acta Universitatis Wratislaviensis” 1998, nr XXXIII.

Reed Doob P., The Idea of the Labyrinth from Classical Antiquity throught the Middle Ages, Cornell, New York-London 1993.

Rybicka E., Formy labiryntu w prozie polskiej XX wieku, Kraków 2000.

Santarcangeli P., Ksiega labiryntu, przeł. I. Bukowski, Warszawa 1982.

Senn W., The Labyrinth as a Structural Principle in Narrative Texts, [w:] The Structure of the Text, ed. F. Udo, Tübingen 1987.

Żyto K., Strategie labiryntowe w filmie fikcji, Łódź 2010. 